\title{
In-Silico Studies on Selected Active Constituents of Corbichonia decumbens Against Allergic Bronchopulmonary Aspergillosis
}

Sreeram S ( $\sim$ sreeramsudhir61@gmail.com )

PSG College of Arts and Science https://orcid.org/0000-0001-8969-0527

Arunprasath A

PSG College of Arts and Science

Revathi P

PSG College of Arts and Science

\section{Research Article}

Keywords: In-silico, Herb Medicine, Herb-drug interaction, Docking Approach, ABPA

Posted Date: May 3rd, 2021

DOl: https://doi.org/10.21203/rs.3.rs-463617/v1

License: (c) (1) This work is licensed under a Creative Commons Attribution 4.0 International License.

Read Full License 


\title{
In- Silico Studies on Selected Active Constituents of Corbichonia decumbens Against Allergic Bronchopulmonary Aspergillosis
}

\author{
Sreeram. $\mathrm{S}^{1^{*}}$, Dr. A. Arunprasath ${ }^{2^{*}} \&$ P. Revathi ${ }^{3}$
}

${ }^{1}$ PSG College of Arts \& Science, PG \& Research Department of Botany, Coimbatore (TN), India ORCID- 0000-0001-8969-0527

${ }^{2}$ PSG College of Arts \& Science, PG \& Research Department of Botany, Coimbatore (TN), India

${ }^{3}$ PSG College of Arts \& Science, PG \& Research Department of Botany, Coimbatore (TN), India

Corresponding Author:

Dr. A. Arunprasath

Assistant Professor,

PG \& Research Department of Botany

PSG College of Arts \& Science

Coimbatore- 14

Tamil Nadu- 641014

E-mail: arunprasath@psgcas.ac.in 


\begin{abstract}
Herbs have been employed in the treatment of various diseases and other medicinal purposes for a long time and they've been the zest of our life. Corbichonia decumbens an erect, short-lived succulent herb is found to possess zenith medicinal properties. At a first, the in-silico activity of the plant has been determined to carry out a modification in the Surfactant Protein-D (SP-D) which plays a pivotal role in defense against the Allergic Bronchopulmonary Aspergillosis (ABPA). The SP-D protein has been modified using in-silico tools thus making it more robust in containing ABPA. The protein SP-D when combined with the plant compound 1-methyl-3,5dinitro-1,2,4-triazole had binding energy of -6.98 and interactions with active site residue ASN-236, LYS-246, GLU-232, PHE-234 and, GLN-236. Being one of the first in-silico works carried out in this plant species it aims to provide a substantial base for future works and unwrap the potential of this herb in all aspects of medicinal plant science.
\end{abstract}

KEYWORDS: In-silico, Herb Medicine, Herb-drug interaction, Docking Approach, ABPA 


\section{Introduction}

The use of plants in the preparation of medicine and ethnobotanical studies is being practiced since time immemorial. The term medicinal plants have been in force since ancient times and these medicinal plants are used in the preparation of traditional medicines. In India, the use of herbs is mentioned in Vedic scriptures. In India, it is believed that the taxonomical rank of classification \& naming of plants in the Sanskrit language is much older than that of Latin and Greek languages and the study dates back to the Vedic period from $2500 \mathrm{BC}$ to $600 \mathrm{BC}$ (Balkrishna, Mishra and Srivastava, 2019). Parts of plants such as fruits, flowers, seed, stem, bark, leaf, stigma, or a root can be classified as herbs nowadays. At first, the 'herb' referred to non-woody plants, as well as those that came from trees and shrubs. The medicinal plants find a varied application in the manufacture of food, flavonoids, medicine, perfumes and also utilized for sacred activities (NHP, 2016). Corbichonia decumbens belonging to the family of Lophiocarpaceae is an erect, prostrate-ascending annual or short-lived perennial succulent herb up to $50 \mathrm{~cm}$. in height, sometimes with woody rootstock found in the pavements in and around the Annur region of Coimbatore. This potential herb can be well utilized as an effective source of the drug for various diseases as they have an intrinsic capacity to synthesize aromatic substances such as phenols, and their derivatives (Geissman, 1963). These secondary metabolites tend to exhibit their therapeutic tendencies. These idiosyncratic attributes of plants are the main reason for the researchers to employ them in the drug preparation to reduce the dependency on inorganic compounds. The ethanolic leaf extract of Corbichonia decumbens displayed a good activity in the antimicrobial assay. The ethanolic leaf extract exhibited a much appreciable zone of inhibition against Aspergillus fumigatus with Ciprofloxacin as standard (DHA \& Arunprasath, 2020). The Gas Chromatography-Mass Spectrometry (GCMS) for C. decumbens ethanolic extract revealed the major 30 compounds which had the bio-potential for becoming an effective drug (Saranya \& Arunprasath, 2019), this preliminary analysis paved the way for the in-silico works that were carried out in this plant. The disease Allergic Bronchopulmonary Aspergillosis (ABPA) results from IgE-induced pulmonary response to aspergillus species (Kanu \& Patel, 2008). ABPA can be classified as a severe condition in children, adolescents, and adults with cystic fibrosis (CF) (M. B. De Almeida et al., 2006). The Surfactant Protein D (SPD) a lung surfactant protein also called collectins are known to interact with carbohydrate structures on the surfaces of a wide range of pathogens, such as viruses, bacteria, and fungi via their carbohydrate recognition domains (CRDs) and enhance phagocytosis and killing by neutrophils and macrophages (Wright, 2005). SP-D is believed to play a vital role in innate immunity in the lungs by binding through its multiple C-type lectin domains to carbohydrate structures present on a range of viruses, bacteria, yeasts, and fungi (Reid, 1998). Bio-informatics tools helped in the successful visualization of the target-compound interactions, as drug discovery programs primarily start with the identifications of suitable drug targets, which are biomolecules such as proteins, enzymes, 
and ion-channels (Terstappen \& Reggiani, 2001). The initial steps of drug validation can be obtained through insilico and animal models, but the outcome can only be obtained through human clinical trials. The study aims to bring out the efficient use of SP-D with the plant compound of $C$. decumbens against ABPA disease and to emphasize the significance of $C$. decumbens as a potential herb as it is one of the first in-silico works in this plant to date.

\section{Materials and methods}

The plant compounds which were already obtained from GC-MS analysis (Saranya \& Arunprasath, 2019) were retrieved from online databases such as;

\section{PDB, PubChem \& Pass Online}

The 3D protein structure for the Surfactant Protein- D (SP-D) is recovered from the Protein Data Bank database (PDB ID: 4M18). Dynamic web page region was anticipated utilizing LigSite online apparatus. The PASS ONLINE predicts 4130 types of biological activities, for which the difference between probabilities will be active $(\mathrm{Pa})$ and probabilities will be inactive $(\mathrm{Pi})$ was calculated. The Pa-Pi values for activities randomly selected from the total list of predicted biological activities will be used as independent regression variables are perused.

Lipinski rule of 5 helps in distinguishing between drug-like and non-drug-like molecules (Yongqiang Zhang et al., 2020). It predicts a high probability of success or failure due to drug-likeness for molecules complying with 2 or more of the following rules.

Molecular mass less than 500 Dalton

$>$ High lipophilicity (expressed as LogP less than 5)

$>$ Less than 5 hydrogen bond donors

$>$ Less than 10 hydrogen bond acceptors

$>$ Molar refractivity must between 40-130

\section{Molecular Docking Study}

MGL tools with AutoGrid4 and AutoDock4 will be used to set up and to perform blind docking calculations between the Ligands and Protein. A crystallized 3-dimensional structure was obtained from the Protein Data Bank (PDB). Receptor (protein) and ligand (complex) files were prepared using Auto Dock Tools. The protein was enclosed in a box with grid points in $\mathrm{x}, \mathrm{y}$, and $\mathrm{z}$ directions and a grid spacing of $0.375 \AA$ (Holt et al., 2008). The center of the grid is set to $-6.516,30.278$, and $-1.951 \AA$. Lamarckian genetic algorithms, as implemented in Auto Dock, were employed to perform docking calculations. All other guidelines are default settings. For every individual docking case, the lowest energy docked confirmation, according to the Auto Dock scoring function and several hydrogen bonds was selected as the binding mode. The output from Auto Dock was rendered with PyMol. 


\section{Pymol}

PyMOL is one of a few open-source visualization tools which are used in structural biology. A part of the software's name refers to the fact that it extends, and is extensible by the Python programming language. All the bindings are visualized by using the Structure Visualizing tool pymol viewer, the interaction between the chemical compounds and target protein (DeLano, 2002).

\section{Results}

The retrieved compounds were analyzed for PASS prediction (Table 1) from which the activity of compounds was confirmed. Further, the compounds were subjected to Absorption, Distribution, Metabolism, and Excretion properties, and the results were tabulated (Table 2). The compounds weren't found to violate Lipinski's rule of five. First-hand knowledge of this information is much necessary before drug discovery as it has a great impact on the cost, labor, and time duration. Lipinski's rule of five is also called Pfizer's rule of five or the rule of thumb to evaluate drug-likeness to indicate the following properties like molecular weight, octanol/water partition coefficient, hydrogen bond donor, and acceptor. The results of docking studies were recorded in (Table 3) and it revealed the compound 1-methyl-3, 5-dinitro-1, 2,4-triazole from Corbichonia decumbens with SP-D shows binding energy of -6.98 (Fig 1). The interactions were observed using Pymol. 
Table 1 Activity of Compounds

\begin{tabular}{|c|c|c|c|}
\hline Compound Name & PubChem ID & $\begin{array}{l}\text { Compound Activity } \\
\text { (Pass Online) }\end{array}$ & \\
\hline Quinoline & 7047 & 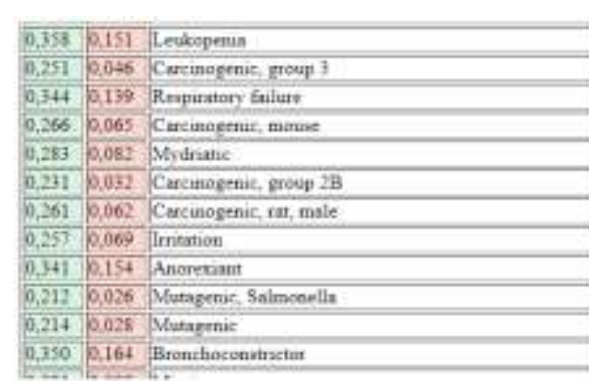 & | \\
\hline Gentisyl alcohol & 188287 & 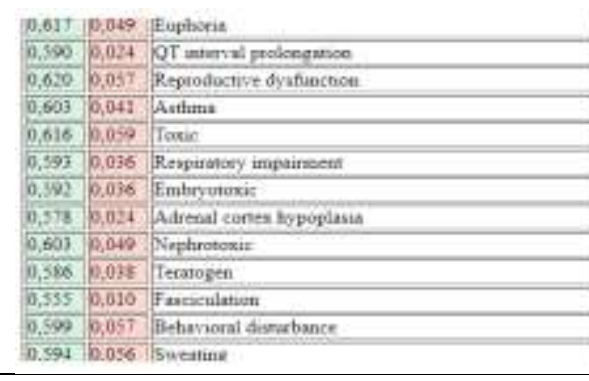 & $=$ \\
\hline $\begin{array}{l}\text { 1,1-Diethoxy-2- } \\
\text { methylpropane }\end{array}$ & 519415 & 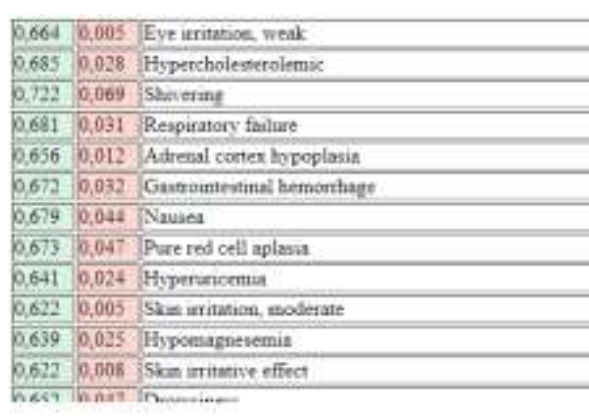 & : \\
\hline $\begin{array}{l}\text { 1-methyl-3,5-dinitro-1,2,4- } \\
\text { triazole }\end{array}$ & 542691 & 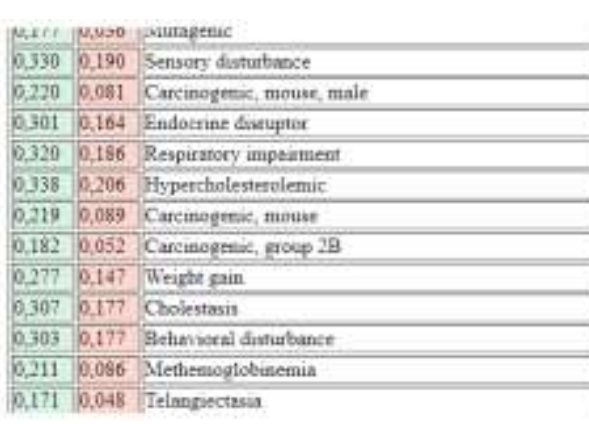 & I \\
\hline
\end{tabular}




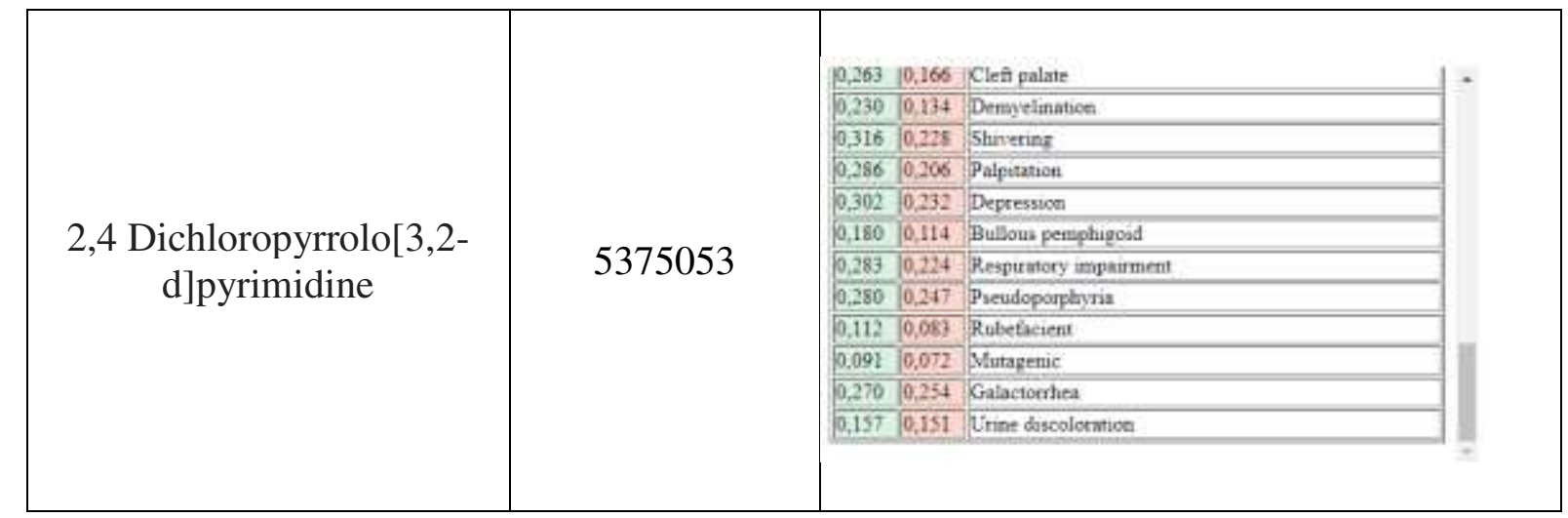

Table 2 ADME Property of plant compound

\begin{tabular}{|c|c|c|c|c|c|c|}
\hline Molecule & $\begin{array}{c}\text { mol_MW } \\
\text { (Molecular } \\
\text { weight })\end{array}$ & $\begin{array}{c}\text { accptHB } \\
\text { (Accepto } \\
\mathbf{r}- \\
\text { Hydroge } \\
\text { n Bonds })\end{array}$ & $\begin{array}{c}\text { donorH B } \\
\text { (Donor - } \\
\text { Hydrogen } \\
\text { Bonds ) }\end{array}$ & $\begin{array}{c}\text { BBB } \\
\text { permeant }\end{array}$ & $\begin{array}{c}\text { GI } \\
\text { Absorption }\end{array}$ & $\begin{array}{c}\text { Rule of Five } \\
\text { (Lipinski's } \\
\text { rule) }\end{array}$ \\
\hline Quinoline & 146.23 & 2 & 0 & Yes & High & 0 \\
\hline Gentisyl alcohol & 173.09 & 6 & 0 & No & High & 0 \\
\hline $\begin{array}{c}\text { 1,1-Diethoxy-2- } \\
\text { methylpropane }\end{array}$ & 129.16 & 1 & 0 & Yes & High & 0 \\
\hline $\begin{array}{c}\text { 1-methyl-3,5-dinitro- } \\
\text { 1,2,4-triazole }\end{array}$ & 140.14 & 3 & 3 & No & High & 0 \\
\hline $\begin{array}{c}\text { 2,4-Dichloropyrrolo[3,2- } \\
\text { d]pyrimidine }\end{array}$ & 188.01 & 2 & 1 & Yes & High & 0 \\
\hline
\end{tabular}

Table 3 Interactions of plant compounds with SP-D

\begin{tabular}{|c|c|c|c|c|}
\hline Name of ligand & Binding energy & $\begin{array}{c}\text { Residues } \\
\text { Interacted }\end{array}$ & $\begin{array}{c}\text { Bond } \\
\text { length }(\AA)\end{array}$ & $\begin{array}{c}\text { No. of } \\
\text { bonds } \\
\text { formed }\end{array}$ \\
\hline Quinoline & -5.25 & GLY-237(C-O) & 3.5 & 1 \\
\hline Gentisyl alcohol & -5.06 & LEU-233(O-H) & 2.3 & 7 \\
\hline
\end{tabular}




\begin{tabular}{|c|c|c|c|c|}
\hline & & $\begin{array}{l}\text { SER-239(H-O) } \\
(\mathrm{O}-\mathrm{N})\end{array}$ & $\begin{array}{l}2.9 \\
2.8\end{array}$ & \\
\hline & & GLN-238(H-N) & 1.9 & \\
\hline & & $(\mathrm{O}-\mathrm{O})$ & 3.5 & \\
\hline & & ALA-264(H-O) & 2.2 & \\
\hline & & GLY-237(O-N) & 3.3 & \\
\hline $\begin{array}{l}\text { 1,1-Diethoxy-2- } \\
\text { methylpropane }\end{array}$ & -3.45 & $\begin{array}{l}\text { LYS-246(O-N) } \\
\qquad(\mathrm{O}-\mathrm{N})\end{array}$ & $\begin{array}{l}3.1 \\
2.7\end{array}$ & 2 \\
\hline \multirow{6}{*}{$\begin{array}{c}\text { 1-methyl-3,5-dinitro- } \\
\text { 1,2,4-triazole }\end{array}$} & \multirow{6}{*}{-6.98} & ASN-236(O-N) & 3.2 & \multirow{6}{*}{7} \\
\hline & & LYS-246(O-N) & 2.8 & \\
\hline & & $\begin{array}{c}\text { GLU-232(O-O) } \\
(\mathrm{N}-\mathrm{O})\end{array}$ & $\begin{array}{l}2.8 \\
3.0\end{array}$ & \\
\hline & & $(\mathrm{O}-\mathrm{O})$ & 3.1 & \\
\hline & & PHE-234(O-O) & 2.9 & \\
\hline & & GLN-236(O-N) & 2.9 & \\
\hline $\begin{array}{c}2,4- \\
\text { Dichloropyrrolo[3,2- } \\
\text { d]pyrimidine }\end{array}$ & -5.17 & GLU-232(H-O) & 2.1 & 1 \\
\hline
\end{tabular}




\section{PYMOL INTERACTIONS}

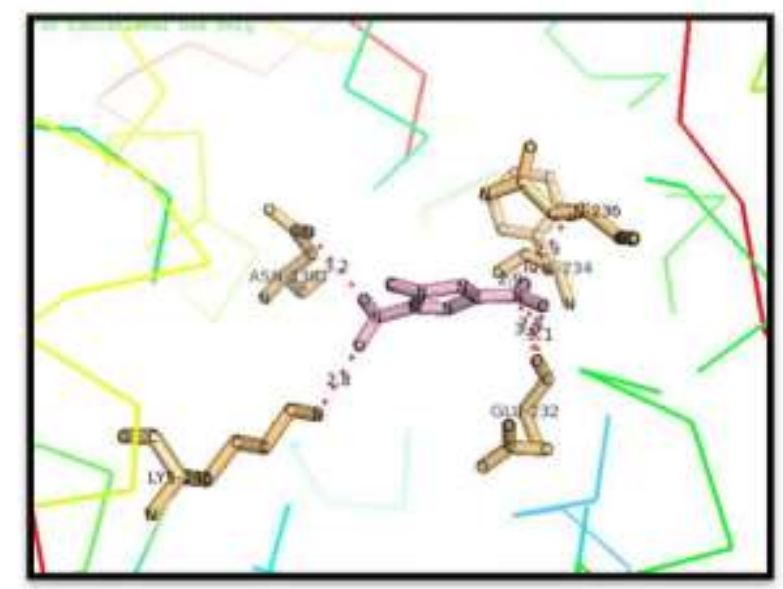

Fig 1 1-methyl-3, 5-dinitro-1, 2, 4-triazole Vs SP-D

This compound displayed excellent binding energy of -6.98.

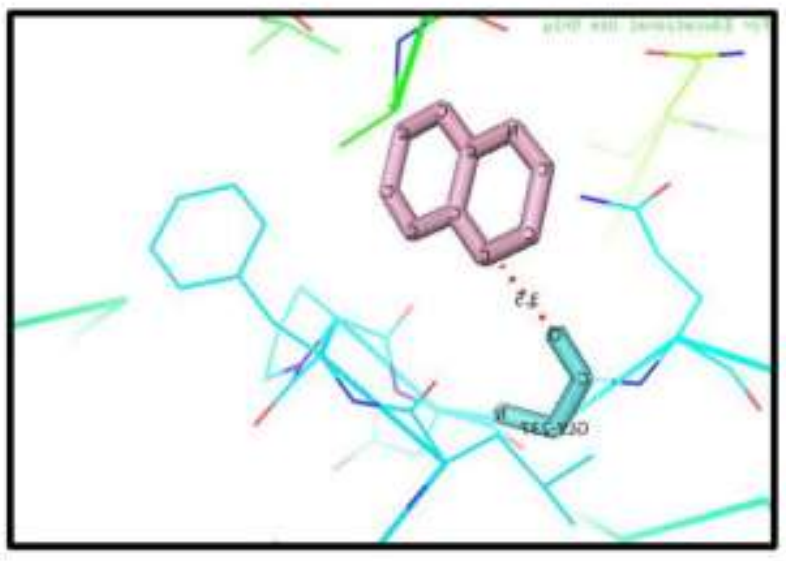

Fig 2 Quinoline Vs SP-D

Binding energy of this compound- 5.25

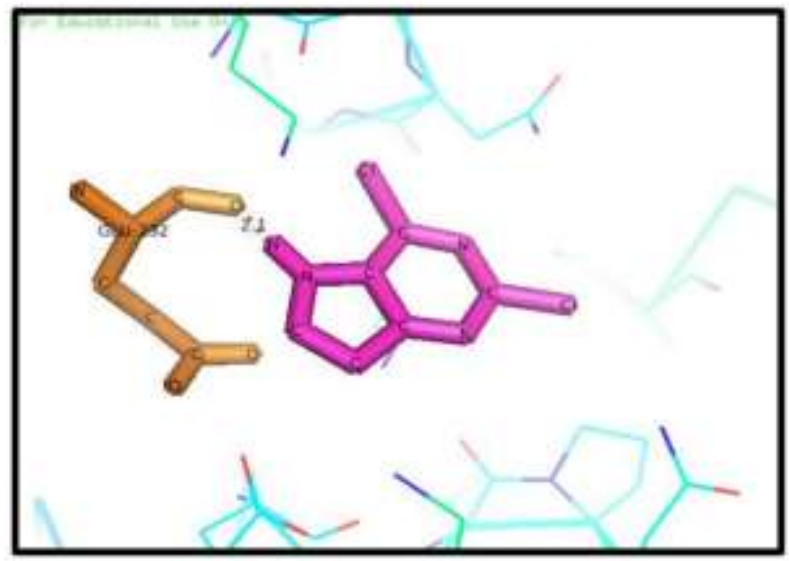

Fig 3 2,4-Dichloropyrrolo[3,2-d]pyrimidine Vs SP-D

Binding Energy of this compound- 5.17 


\section{Discussion}

The disease Allergic Bronchopulmonary Aspergillosis (ABPA), caused by the fungi Aspergillus fumigatus is a hypersensitivity lung disease which is rarely found in 10\% of persons having cystic fibrosis (Keown et al., 2019).

A positive response to this disease was created using the in-silico tools which succored in the successful docking analysis. The ABPA is more ubiquitous in patients who have been diagnosed of asthma (David et al., 1999). The compounds displayed an acceptable binding energy with surfactant protein D, as these are lung surfactant related hydrophilic proteins that have been implicated in surfactant homeostasis and pulmonary innate immunity (U. Kishore et al., 2002). It is believed that synthesis and secretion of this collectin increases with acute injury and epithelial activation (Dennis R. Voelker et al., 2005). Binding of SP-D with this phyto-compounds will surely aid in the development of a more activated protein target which in-turn can produce striking result thereby providing an insight into the development and modification of a target in the fungal disease caused by A. fumigatus. The docking studies of 1-methyl-3, 5-dinitro-1, 2, 4-triazole with SP-D revealed 5 active sites, a similar result was also shown in the transport of GLUT-1 (Richard J. Naftalin et al., 2006). As to get a conclusive result the same receptor was docked with five different ligands so as to bring out the variance. A similar work was carried to evaluate the ability of each docking protocol in order to identify the binding of the same receptor with two different ligands (Ricci and Netz et al., 2009).

\section{CONCLUSION}

The chemical compound 1-methyl-3,5-dinitro-1,2,4-triazole had a much significant binding energy of -6.98 and interactions with active site residue ASN-236, LYS-246, GLU-232, PHE-234 and, GLN-236. A wide variety of compounds were selected for this study but after the scrutinizing only handful of standard compounds were considered. The above plant compounds could be explored more for ABPA \& the identification of an efficient and potential drug molecule by enhancing the activity of SP-D protein and thus making it a super protein by combining this compound.

\section{AUTHOR CONTRIBUTIONS}

Arunprasath- Conceptualization, supervision and review. Sreeram- Methodology, data extraction, writingoriginal draft preparation. Revathi- Data Analysis

\section{FUNDING}

No funds, grants, or other support was received.

\section{DECLARATIONS}

\section{Conflict of Interest}

There are no conflict of interest in this study to declare. 


\section{REFERENCES}

1. Balkrishna, A., Mishra, R. K., Srivastava, A., Joshi, B., Marde, R., \& Prajapati, U. B. (2019). Ancient Indian rishi's (Sages) knowledge of botany and medicinal plants since Vedic period was much older than the period of Theophrastus, A case study-who was the actual father of botany? Int. j. Unani integr. Medicine, 3, 40-44.

2. Introduction and Importance of Medicinal Plants and Herbs | National Health Portal of India (2016). https://www.nhp.gov.in/introduction-and-importance-of-medicinal-plants-and-herbs_mtl

3. Geissman, T. A. (1963). Flavonoid compounds, tannins, lignins and, related compounds. In Compr. Biochem. Vol. 9, pp. 213-250. https://doi.org/10.1016/B978-1-4831-9718-0.50018-7.

4. Vidyacharani, d., \& Arunprasath, a. (2020). Evaluations of secondary metabolites antioxidant and antimicrobial potential in leaf extracts of Corbichonia decumbens (FORSSK.) EXELL. Asian J Pharm Clin Res, 13(11), 181-183. https://doi.org/10.22159/ajpcr.2020.v13i11.39004.

5. Saranya, M. S., \& Arunprasath, A. (2019). Evaluation of phytochemical compounds in Corbichonia decumbens (Frossk). Excell by using Gas Chromatography-Mass Spectrometry. J. App and Adv. Res., 4(3), 89-93.

6. Kanu, A., \& Patel, K. (2008). Treatment of allergic bronchopulmonary aspergillosis (ABPA) in CF with anti-IgE antibody (omalizumab). Pediatr.Pulmonol 43(12),

1249-1251. https://doi.org/10.1002/ppul.20907.

7. de Almeida, M. B., Bussamra, M. H. F., \& Rodrigues, J. C. (2006). Allergic bronchopulmonary aspergillosis in paediatric cystic fibrosis patients. Paediatr. Respir. Rev. 7(1), 67-72. https://doi.org/10.1016/j.prrv.2005.09.003

8. Wright, J. R. (2005). Immunoregulatory functions of surfactant proteins. Nat. Rev. Immunol. 5(1), 58-68. https://doi.org/10.1038/nri1528

9. Reid, K. B. (1998). Interactions of surfactant protein $D$ with pathogens, allergens and phagocytes. Biochimica et biophysica acta (BBA) - Mol Basis Dis, 1408(2-3), 290-295. https://doi.org/10.1016/S0925-4439(98)00074-X

10. Terstappen, G. C., \& Reggiani, A. (2001). In silico research in drug discovery. Trends Pharmacol. Sci., 22(1), 23-26. https://doi.org/10.1016/S0165-6147(00)01584-4.

11. Chen, X., Li, H., Tian, L., Li, Q., Luo, J., \& Zhang, Y. (2020). Analysis of the Physicochemical Properties of Acaricides Based on Lipinski's Rule of Five. J. Comput. Biol, 27(9), 1397-1406. https://doi.org/10.1089/cmb.2019.0323 
12. Holt, P. A., Chaires, J. B., \& Trent, J. O. (2008). Molecular docking of intercalators and groove-binders to nucleic acids using Autodock and Surflex. J Chem Inf Model, 48(8), 1602-1615. https://doi.org/10.1021/ci800063v.

13. DeLano,W.L.(2002).PyMOL. http://virology.wisc.edu/acp/Classes/DropFolders/Drop660_lectures/2013_660/L01_PyMOL_2013r.pdf

14. Keown, K., Abbott, S., Kuzeljevic, B., Rayment, J. H., Chilvers, M. A., \& Yang, C. L. (2019). An investigation into biomarkers for the diagnosis of ABPA and aspergillus disease in cystic fibrosis. Pediatr.Pulmonol 54(11), 1787-1793. https://doi.org/10.1002/ppul.24465.

15. Geller, D. E., Kaplowitz, H., Light, M. J., \& Colin, A. A. (1999). Allergic bronchopulmonary aspergillosis in cystic fibrosis: reported prevalence, regional distribution, and patient characteristics. Chest, 116(3), 639-646. https://doi.org/10.1378/chest.116.3.639.

16. Kishore, U., Madan, T., Sarma, P. U., Singh, M., Urban, B. C., \& Reid, K. B. (2002). Protective roles of pulmonary surfactant proteins, SP-A and SP-D, against lung allergy and infection caused by Aspergillus fumigatus. Immunobiology, 205(4-5), 610-618. https://doi.org/10.1078/0171-2985-00158.

17. Piboonpocanun, S., Chiba, H., Mitsuzawa, H., Martin, W., Murphy, R. C., Harbeck, R. J., \& Voelker, D. R. (2005). Surfactant protein A binds Mycoplasma pneumoniae with high affinity and attenuates its growth by recognition of disaturated phosphatidylglycerols. J. Biol. Chem., 280(1), 9-17. https://doi.org/10.1074/jbc.M411570200.

18. Cunningham, P., Afzal-Ahmed, I., \& Naftalin, R. J. (2006). Docking studies show that D-glucose and quercetin slide through the transporter GLUT1. J. Biol. Chem, 281(9), 5797-5803. https://doi.org/10.1074/jbc.M509422200.

19. Ricci, C. G., \& Netz, P. A. (2009). Docking studies on DNA-ligand interactions: building and application of a protocol to identify the binding mode. J. Chem. Inf. Model., 49(8), 1925-1935. https://doi.org/10.1021/ci9001537. 
Figures

\section{PYMOL INTERACTIONS}

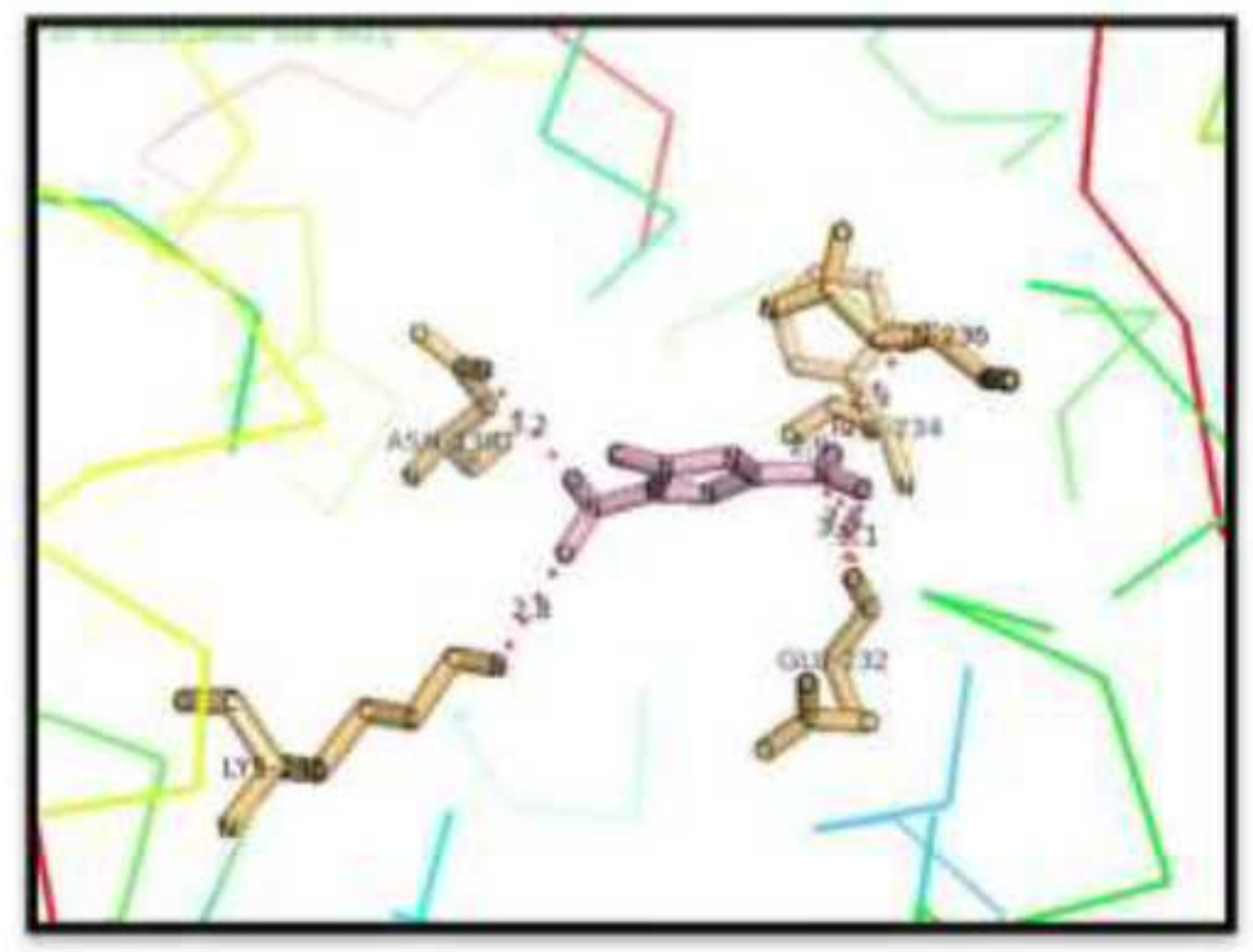

Fig 1 1-methyl-3, 5-dinitro-1, 2, 4-triazole Vs SP-D

This compound displayed excellent binding energy of -6.98.

\section{Figure 1}

Please view the figure caption in the figure 


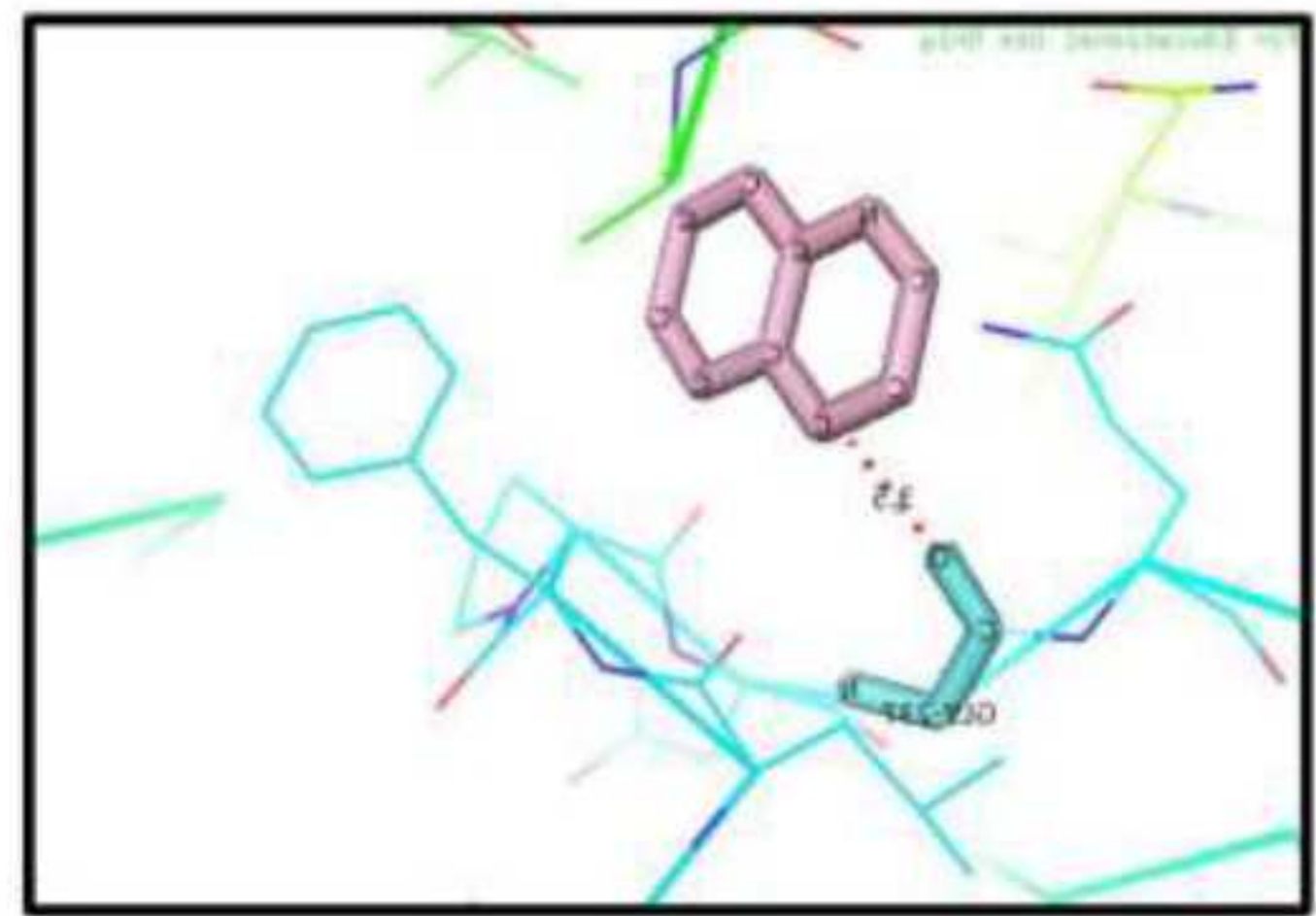

Fig 2 Quinoline Vs SP-D

Binding energy of this compound- 5.25

Figure 2

Please view the figure caption in the figure 


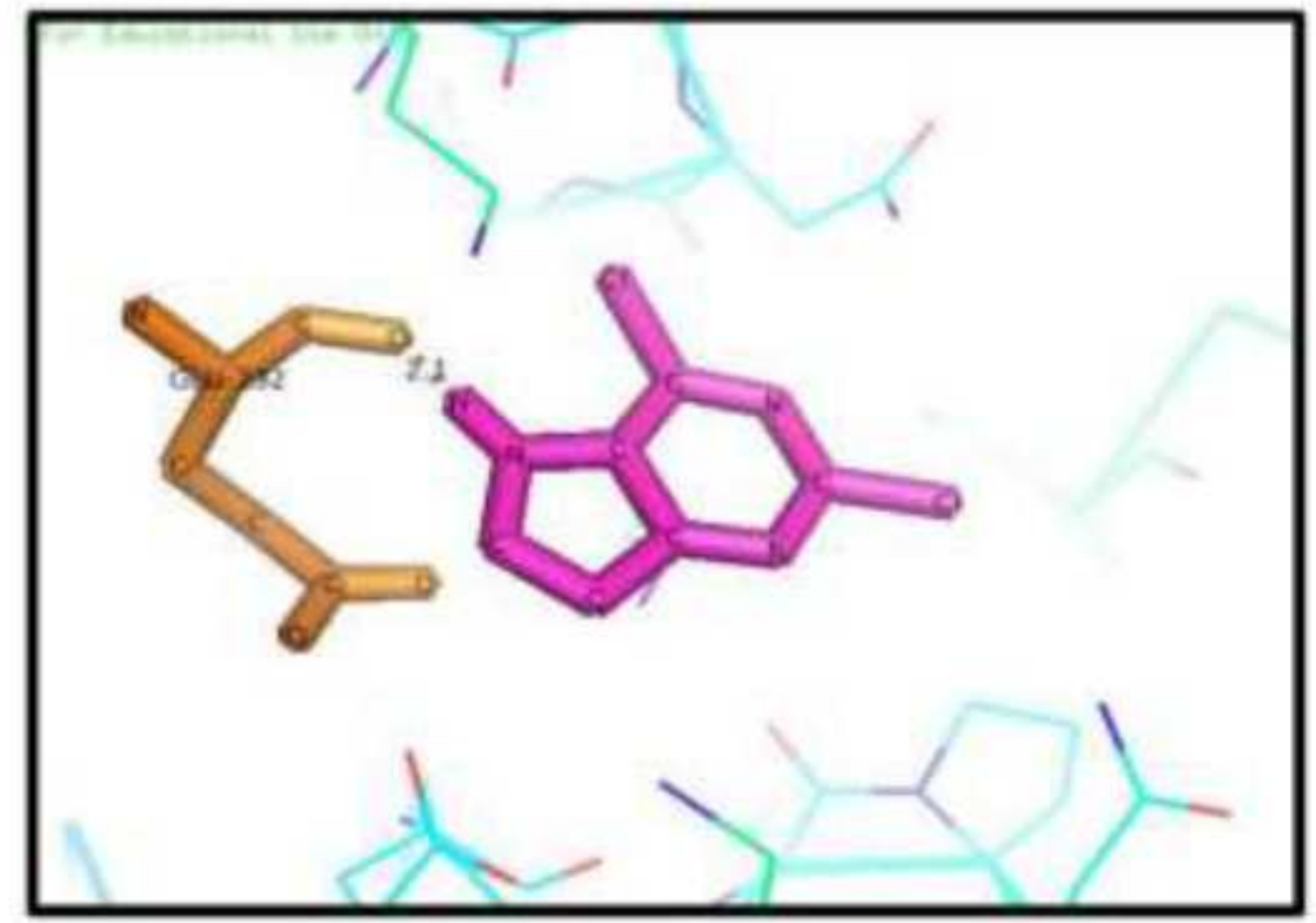

Fig 3 2,4-Dichloropyrrolo[3,2-d]pyrimidine Vs SP-D

\section{Binding Energy of this compound- 5.17}

Figure 3

Please view the figure caption in the figure 